Leonard Bernstein 
This page intentionally left blank 


\section{Leonard Bernstein}

The Political Life of an American Musician

\section{Barry Seldes}

\section{甲}

UNIVERSITY OF CALIFORNIA PRESS

$$
\text { Berkeley Los Angeles London }
$$




\section{MASS: A THEATRE PIECE FOR SINGERS, PLAYERS AND DANCERS}

(C) Copyright 197I by Amberson Holdings LLC and Stephen Schwartz

Leonard Bernstein Music Publishing Company LLC, Publisher

Boosey \& Hawkes, Inc., Sole Agent

Reprinted by permission

\section{KADDISH (SYMPHONY NO. 3)}

(C) Copyright 1963, I967 by Amberson Holdings LLC, Copyright renewed. Leonard Bernstein Music Publishing Company LLC, Publisher

Boosey \& Hawkes, Inc., Sole Agent

Reprinted by permission.

University of California Press, one of the most distinguished university presses in the United States, enriches lives around the world by advancing scholarship in the humanities, social sciences, and natural sciences. Its activities are supported by the UC Press Foundation and by philanthropic contributions from individuals and institutions. For more information, visit www.ucpress.edu.

University of California Press

Berkeley and Los Angeles, California

University of California Press, Ltd.

London, England

(C) 2009 by The Regents of the University of California

Library of Congress Cataloging-in-Publication Data

Seldes, Barry.

Leonard Bernstein : the political life of an American musician /

Barry Seldes.

p. $\mathrm{cm}$.

Includes bibliographical references and index.

ISBN: 978-0-520-25764-I (cloth : alk. paper)

I. Bernstein, Leonard, I918-I990-Political activity. 2. Bernstein,

Leonard, 1918-1990-Political and social views. 3. Musicians-United States-Political activity. I. Title.

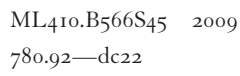
2008040829

Manufactured in the United States of America
$\begin{array}{llllllllll}\text { I8 } & \text { I7 } & \text { I6 } & \text { I5 } & \text { I4 } & \text { I3 } & \text { I2 } & \text { II } & \text { IO } & 09\end{array}$

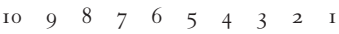

This book is printed on Natures Book, which contains $50 \%$ post-consumer waste and meets the minimum requirements of ANsI/NIso Z39.48-I992 (R 1997) (Permanence of Paper). 
To the memory of Gertrude Seldes (1912-1983)

Nathan Seldes (1909-1979) 
This page intentionally left blank 
You have a ... task.... It is to establish from all these freewheeling personalities within your States a tie that shall be as a blood-bond. Their lives are of many moods and colors. Build them into a great Cathedral. Their voices are unconscious and spontaneous and discordant. Compose from them a symphony.

Romain Rolland, "America and the Arts"

The fatal shortcoming of nine-tenths of the music produced in America is its utter innocence of any vital relationship to the community.

\section{Paul Rosenfeld, "The American Composer"}

The objective conditions necessary to the realization of a work of art are, as we know, a highly complex phenomenon, involving one's public, the possibility of contact with it, the general atmosphere, and above all freedom from involuntary subjective control.

Czeslaw Milosz, The Captive Mind 
This page intentionally left blank 